\title{
UTILIZATION OF SOME FRUITS AND VEGETABLES WASTES AS A SOURCE OF DIETARY FIBERS IN CAKE MAKING \\ Sharoba, A.M. ${ }^{*}$; M. A. Farrag ${ }^{\star *}$ and A. M. A. Abd El-Salam ${ }^{\star *}$ \\ * Food Sci. Dept., Moshtohor Fac. of Agric. Banha Univ., Egypt. \\ ${ }^{\star *}$ Food Technology Res. Institute, Agric. Res. Center, Giza, Egypt.
}

\begin{abstract}
In this study, feasibility of using orange waste (OW), carrot pomace (CP), potato peels (PP) and green pea peels (GPP) wastes from food industry, as a starting raw material to produce dietary fibre powders and the feasibility of producing cakes intended for people suffering from obesity or over weight and diabetes. The physicochemical properties of dietary fiber powder were first evaluated. The results showed that the fibre contents, compositions and hydration properties (water and oil holding capacity and swelling capacity) of the fiber powder. Some food processing wastes $\{(\mathrm{OW}),(\mathrm{CP}),(\mathrm{PP})$ and $(\mathrm{GPP})\}$, are a rich sources of fibres. The OW, CP, PP and GPP wastes were replaced with wheat flour (72\%) at 5, 10, 15 and 20\% levels and studied for rheological characteristics. Water absorption increased significantly with increasing wastes from 0 to $20 \%$. Dough stability and dough development were increased. Resistance to extension values significantly increased, whereas extensibility values decreased. The produced fiber substituted cakes achieved a reduction in calories. Cakes were prepared from blends of wheat flour (72\%) with 5 , 10,15 and $20 \%$ fruits and vegetables wastes. The volume of cakes decreased with increase in fruits and vegetables wastes content from 0 to $20 \%$. Cakes prepared from $20 \%$ of wastes OW, CP, PP and GPP had a higher ratio of dietary fibres. Sensory evaluation showed that all high fiber substituted cake samples were significantly lower than control cake sample in all sensory characteristics, except cake samples prepared with 5 and $10 \%$ of orange waste and carrot pomace had no significant differences $(P>0.05)$ with control cake. However, there were significant differences between cake samples containing the same type of fiber source at 5, 10, 15 and $20 \%$ replacement levels. The highest and lowest scores in the same type of fiber source for all attributes were that achieved by cake samples with fiber source at 5 and $20 \%$ replacement levels, respectively. Texture properties of cake were affected by replacement levels of fiber source. The results indicated that OW, CP, PP and GPP wastes can serve as a good source of dietary fibres.

Keywords: Food processing wastes; dietary fibers; orange waste, carrot pomace, potato peels, green pea peels; cakes; rheological, sensory and texture characteristics.
\end{abstract}

\section{INTRODUCTION}

Dietary fiber (DF) consists of a variety of non starch polysaccharides which include cellulose, hemicellulose, pectin, B-glucans, gums and lignin (Lamghari et al., 2000 and Gallaher and Schneeman, 2001). However, the SDF/IDF ratio is important for both, dietary and functional properties. It is generally accepted that those fiber sources suitable for use as food ingredient should have an SDF/IDF ratio close to 1:2 (Jaime et al., 2002). Dietary fiber is composed mainly by remnants of edible plant cells; parenchymatous tissues 
are known to be the most important source of fiber, cell walls of fruits, vegetables, pulses and cereals make up most of the dietary fibre intake (Jimenez et al., 2000).

Dietary fiber plays an important role in human health, they acts as a protective agent against cardiovascular diseases, diverticulosis, constipation, irritable colon, colon cancer and diabetes (Gorinstein et al., 2001 and Rodriguez et al., 2006). Fiber derived from fruits and vegetables have a considerably higher proportion of soluble dietary fiber, whereas cereal fibres contain more insoluble cellulose and hemicellulose (Redgwell and Fischer, 2005 and Herbafood, 2002). The physiological effects are related to the physicochemical and functional properties of dietary fibre. It is widely known that dietary fibres obtained by different methods and from different sources, behave differently during their transit through the gastrointestinal tract, depending on their chemical composition and physicochemical characteristics and on the processing that food undergo (Jimenez et al., 2000; Herbafood, 2002 and Chau and Huang, 2003). While a few years ago the sub products generated during the processing of plant food constituted an economic and environmental problem, today they are considered a promising source of functional compounds (Carle et al., 2001).

They are many fruits, for example orange, apple and peach, which are used for the extraction of their juices. They all contain a by-product from which can be recovered different high-added value compounds; among those, it is remarkable the fibre fraction that has a great potential in the preparation of functional foods. There are also several vegetables, such as carrot, potato, green pea, pepper, artichoke, onion and asparagus that originate a waste during their processing (Rodriguez et al., 1999 and Rodriguez et al., 2006) and it contains both soluble and insoluble fibre compounds that can be used for designing new 'functional foods'. Orange and other fruits which are mainly commercialized in processed form originate great amounts of sub-products consisting of peels, bones and seeds. This material could be a restrictive factor in the commercialization of these products if it is not usefully recovered, because it represents significant losses with respect to the raw material, which considerably increases the price of the processed products (Schieber et al., 2001).

Potato peels consider as a rich source of fibers, since it contains about 9.7 to $68 \%$ from its total weight, Mullin et al. (1993). The potatoes are the most commonly consumed vegetables worldwide, whereas the potatoes production stands at 293 million metric tons. The annual production of Egypt is 2.2 million tons. As results, a large quantity of potato peel waste is generated.

Green peas (Pisum Sativum) which is one of the most important vegetable processing crop in Egypt and it's by product (peels) resembles about $50 \%$. Dietary fibres from different sources have been used to replace wheat flour in the preparation of bakery products. Potato peel, a by-product from potato industry, rich in dietary fibre, was used as a source of dietary fiber in bread making (Toma et al., 1979).

Plant fibres show some functional properties, such us water-holding capacity (WHC) and swelling capacity (SWC) which have been more useful 
for understanding the physiological effect of dietary fiber, than the chemical composition alone (Femenia et al., 1997; Gallaher and Schneeman, 2001). Functional properties of plant fibre depend on the IDF/SDF ratio, particle size, extraction condition and vegetable source (Jaime et al., 2002). The main characteristics of the commercialized fiber product are: total dietary fiber content above $50 \%$, moisture lower than $9 \%$, low content of lipids, a low caloric value and neutral flavour and taste (Larrauri et al., 1997 and Larrauri 1999). In order to take advantage of the dietary and functional properties of fibre, some high dietary fibre formulated foods are currently being developed (Grigelmo-Miguel and Martin-Belloso, 1999; Herbafood, 2002; Tudorica et al., 2002). According to Larrauri (1999), the "ideal dietary fibre" should meet, among others, the following requirements; have no nutritionally objectionable components, be as concentrated as possible, be bland in taste, color and odor; have a balanced composition; have a good shelf life; be compatible with food processing; have the expected physiological effects. It must be kept in mind that fiber enrichment not only influences the overall quality of food by changing its physiological properties, but also significantly affects the sensorial properties of a product. When plant fibres are added to a food product, they contribute to water holding properties and texture of the product (Kethireddipalli et al., 2002). Fruit fibre have better quality due to higher total and soluble fibre content, water and oil holding capacity (Larrauri, 1999). Residues from orange juice extraction are potentially an excellent source of DF because this material is rich in pectin and may be available in large quantities (Fernandez-Gines et al., 2003). Dietary fibres are not only desirable for their nutritional properties, but also for their functional and technological properties and because of those they can also be used to upgrade agricultural products and by products for use as food ingredients (Schieber et al., 2001). The industry of fruit juice produces significant amounts of by-products which could cause problems in their disposal. Usually, these products are used in animal feeding. However, their high amount of dietary fiber could permit the use of them in developing new natural ingredients for the food industry. According to the Statistical Database of the Food and Agriculture Organization of the United Nations (FAOSTAT), world orange production in 2007 was estimated to be $63,906,094$ tons. A high percentage of this production $(70 \%)$ is used to manufacture products such as juice or marmalade. Moreover, approximately $50-60 \%$ of the processed fruit is transformed into citrus peel waste, which is composed of the peel, seeds and membrane residues (Wilkins et al., 2007). In order to prevent problems related to the disposal of this product and environmental concerns, this waste must be properly processed. Under current environmental legislation, all waste must be considered raw material if a valorization procedure is to be developed.

Accordingly, the purpose of this work was a trial to evaluate some functional properties of fibre obtained from orange waste, carrot pomace, potato peels and green pea peels wastes, in order to use them as a dietary fibres source in the enrichment of cakes. The obtained cakes were evaluated mechanically, physically and organoliptically. 


\section{MATERIALS AND METHODS}

Materials:

Wheat flour: Wheat flour (soft) $(72 \%)$, were obtained from the South Cairo Mills Company, Cairo, Egypt.

Baking Ingredients: skim dry milk, sugar, margarine, corn oil, eggs, vanilla and baking powder were obtained from local market Kaha city, Kaliobia, Egypt.

Orange waste (Citrus sinensis) Balady orange variety: were obtained from Kaha company for canned food, Kaha city, Kaliobia, Egypt.

Carrot pomace (Daucus carota L.): was obtained from Kaha company for canned food, Kaha city, Kaliobia, Egypt.

Potato peels (Solanum tuberosum L.): were obtained as a waste from Egypt Foods factory for chipsy products, Industrial zone, Minufiya, Egypt.

Green pea peels (Pisum Sativum): were obtained from Kaha Company for canned food, Kaha city, Kaliobia, Egypt.

Preparation dietary fiber powders

-Orange waste fibres: the by-products obtained from orange peel and the remaining pulp after juice extraction could be suitable sources of DF by cutting, extraction of juice, peel residue chopping, the material was washed under mild conditions to avoid or minimize losses of some soluble fiber components (such as pectins and pentosans) as well as bioactive components (such as flavonoids, polyphenols and carotenes) (Larrauri, 1999), then dried at temperatures below $65{ }^{\circ} \mathrm{C}$ avoids changes in the functional properties and in the content of polyphenols, tannins, anthocyanidins and proteins for $12 \mathrm{hrs}$. in an electric oven drier, and grinding to a particle size of 500-600 $\mu \mathrm{m}$, according to (Kethireddipalli et al., 2002).

-Carrot pomace fibers: Carrot pomace was washed twice with warm water $\left(30{ }^{\circ} \mathrm{C}\right)$; then it was dried at $60{ }^{\circ} \mathrm{C}$ for $12 \mathrm{hrs}$.in an electric oven drier and ground to a particle size of 500-600 $\mu$ m.to pass through 20 mesh sieve packed in polyethylene bags and stored in refrigerator until use.

-Potato peels fiber: potato peels obtained and thoroughly washed on a multilayer of cheese cloth using tape water and then dried in an electric oven at $60{ }^{\circ} \mathrm{C}$ for $12 \mathrm{hrs}$. to prepare dried potato peels.

-Green pea peels fiber: green pea peels were washed with water; then it was dried at $60{ }^{\circ} \mathrm{C}$ for $12 \mathrm{hrs}$. in an electric oven drier and ground to a particle size of $500-600 \mu \mathrm{m}$. to pass through 20 mesh sieve packed in polyethylene bags and stored in refrigerator until use.

The fibre materials were then finely milled using the laboratory hammer mill, and sieved through a 500- $\mu \mathrm{m}$ sieve size into fine powder. Four batches of fibre flours were prepared. The fibres were assigned names, orange waste fibre (OWF), Carrot pomace fibre (CPF), Potato peels fibre (PPF) and Green pea peels fibre (GPPF), then packaged in polythene bags protected from light and moisture and stored at refrigerator temperature until further analysed. 


\section{Processing: \\ Preparation of cakes}

The corn oil was beaten thoroughly, the sugar was added to butter and mixed until got smooth like cream, and then a well blended egg with vanillia were added and mixed together. The blends soft wheat flour $(72 \%)$ with dietary fibre sources (orange waste fibre (OWF), Carrot pomace fibre (CPF), Potato peels fibre (PPF) and Green pea peels fibre (GPPF) these byproducts were replaced with wheat flour at $5,10,15$ and $20 \%$ levels, baking powder were stirred together and added alternately to the egg mixture. The mixture was whipped until got smooth. The dough transferred to a greased pan and was baked for $25 \mathrm{~min}$. at $200 \pm 5^{\circ} \mathrm{C}$ then was cooled at room temperature (AACC, 2002). Cakes were prepared according to the formula is shown in Table (I).

Table (I): Cake formula:

\begin{tabular}{|l|c|}
\hline \multicolumn{1}{|c|}{ Ingredients } & Weight (g) \\
\hline Soft wheat flour (72\% extraction ) & 150.00 \\
\hline Baking powder & 6.81 \\
\hline Salt & 3.40 \\
\hline Sugar & 75.00 \\
\hline Corn oil & 31.83 \\
\hline Fresh whole egg & 39.75 \\
\hline Skim dry milk & 14.76 \\
\hline Vanilla & 1.50 \\
\hline
\end{tabular}

\section{Analytical methods: \\ Proximate chemical composition:}

Moisture, crude protein, crude lipid, ash and carbohydrate contents were determined using the appropriate AOAC (2000).

Carbohydrates were determined by difference from the total dietary fibre, lipids, protein and ash contents (Chau and Huang, 2003).

Determination of dietary fiber contents:

Total dietary fiber (TDF), soluble dietary fibre (SDF) and insoluble dietary fiber (IDF) contents of samples were determined with an enzymaticgravimetric procedure according to AOAC Method 991.43, (AOAC, 2000 and Lee et al., 1992).

\section{Functional properties:}

Water holding capacity $(\mathrm{WHC})$ and oil holding capacity $(\mathrm{OHC})$ were measured according the methods reported by Femenia et al. (1997) and Robertson et al. (2000).

Swelling capacity (SWC): Was measured using the bed volume technique described by Kuniak and Marchessault (1972).

Triplicate measurements were taken for all WHC, OHC and SWC.

\section{Rheological characteristics:}

Fruits and vegetables waste blends at 0, 5, 10, 15 and $20 \%$ levels were prepared by replacing wheat flour. The effect of fruits and vegetables fiber on the mixing profile of the dough was studied using farinograph (Brabender, Duisburg, Germany) according to the standard AACC methods 
(2000). Farinograph test was carried out to determine the water absorption, arrival time, dough development time, dough stability and degree of weakening.

The elastic properties of the dough were studied using extensograph (Brabender, Duisburg, Germany) according to the standard AACC methods (2000). Extensograph test was carried out to determine resistance to extension (B.U.), extensibility ( $\mathrm{mm})$, proportional number and energy $\left(\mathrm{cm}^{2}\right)$.

Physical characteristics for cakes:

The weight $(\mathrm{g})$ for cake was determined individually within one hour after baking the average was recorded.

The volume $\left(\mathrm{cm}^{3}\right)$ of different types of produced cakes was determined by rape seeds displacement method according to (AACC, 2000). Specific volume was calculated according to the method of (AACC, 2000), using the following equation

Texture characteristics:

Specific volume $=$ Volume $\left(\mathrm{cm}^{3}\right) /$ Weight $(\mathrm{g})$.

The texture of the cakes was measured objectively using food texturometer (TAHDi, Stable Micro System, UK) as per the standard AACC methods (2000). A test speed of $2.0 \mathrm{~mm} \mathrm{~s}^{-1}$ were used. A $35 \mathrm{~mm}$ diameter cylinder aluminum probe (P-35), was used to measure the required compression force. Force required to compress $25 \%$ of the cake slice $(2.54$ $\mathrm{cm})$ was recorded. All measurements were performed at ambient temperature $25 \pm 2^{\circ} \mathrm{C}$ according to Gomez et al. (2007).

Mechanical properties measurements:

All mechanical properties were made using the Instron Universal Testing Machine (Model 4401) equipped with: 5-mm diameter tip probe for penetration test (with 100, 500, 1000 and $5000 \mathrm{~N}$ load cell). All testing was performed at room temperature $\left(25 \pm 2^{\circ} \mathrm{C}\right)$.

\section{Penetration test (PT):}

Each piece of tested cakes was placed in a hole of the bevelled ring. The pin penetrated with a constant speed $10 \mathrm{~mm} \cdot \mathrm{min}^{-1}$ into each piece of cakes tested. Three penetration points at different parts for each piece of cakes and 5 piece for each sample were taken for each test condition, recording the force profile at $1 \mathrm{~cm}$ of probe penetration (Femenia et al., 1997). Force - deformation curves were recorded and hardness was derived as indicators of textural properties. Each sample was used for only one measurement.

\section{Mechanical measurements analysis:}

1- The force corresponding to the maximum puncture is defined as the maximum force $\left(F_{\max }\right)$. The maximum puncture force $\left(F_{\max }\right)$ was measured in Newtons (N), as mentioned by Sharoba et al. (2012) and Saleh et al. (2012).

2- Maximum deformation: the distance from beginning to distance at maximum force.

3- Hardness = Maximum force $(\mathrm{N})$ / Maximum deformation $(\mathrm{mm})$, as mentioned by Sharoba et al. (2012) and Saleh et al. (2012).

Sensory analysis

Sensory evaluation of cakes were carried out in a standardized test room in morning sessions (11:00-13:00 h) by a 12 trained sensory panel, and 
were carried out by a properly well trained panel of 12 panelists. They were selected if their individual scores in 10 different tests showed a reproducibility of $90 \%$. The 12 member internal panel evaluated on a five point hedonic scale, scoring was based on a 100 point scale $(10-100)$ where $(90-100)=$ excellent, $(70-80)=$ very good, $(50-60)=$ good, $(30-40)=$ fair and $(10-20)=$ poor. Mineral water was used by the panelists to rinse the mouth between samples, according to the method described by (AACC, 2002), cake samples were left to cool at room temperature for $1 \mathrm{hr}$. after baking. Then cake was cut with a sharp knife and subjected to panel test. Cells 30 (uniformity 10, size of cells 10 , and thickness of walls 10 ), grain 20, texture 30 (moistness 10 , tenderness 10 , and softness 10 ), crumb color 10 , flavor 10 and overall acceptability 100 degrees.

\section{Statistical analysis:}

Each sample was prepared in triplicate and analysed twice. Data are presented as the average of three analyses and data was analysed using the analysis of variance (ANOVA) $p<0.05$ was considered to be statistically significant, followed by multiple comparisons using least significant difference, (L.S.D.0.05)(Gomez and Gomez, 1984).

\section{RESULTS AND DISCUSSION}

Nowadays, there is a considerable interest in studying the feasibility of using by-products from food processing plants as raw materials for production of dietary fiber powder since these wastes are inexpensive and highly abundant. Fruits and vegetables wastes or residues are among the most promising by-products with high dietary fiber content, and possess a good balance between SDF and IDF Proximate chemical composition of wheat flour $(72 \%)$ :

Data in Table (1) represent the proximate chemical composition of wheat flour (72\%) of protein, fat, ash, crude fiber, total carbohydrates contents on (dry weight basis) and moisture contents. From these results the wheat flour was suitable for used to make cake.

Table (1): Chemical composition of wheat flour (72\%).

\begin{tabular}{|l|c|}
\hline \multicolumn{1}{|c|}{ Components } & $\%$ \\
\hline Moisture & $11.99 \pm 0.292$ \\
\hline Protein $^{\star}$ & $11.85 \pm 0.401$ \\
\hline Fat $^{\star}$ & $1.06 \pm 0.068$ \\
\hline Ash $^{*}$ & $0.52 \pm 0.018$ \\
\hline Crude fiber $^{*}$ & $0.54 \pm 0.034$ \\
\hline Available carbohydrates ${ }^{*}$ & 86.04 \\
\hline${ }^{*}$ (on dry weight basis) & ${ }^{*}$ : Available carbohydrate by difference \\
\hline
\end{tabular}

Chemical composition, fiber content and functional properties of used fruits and vegetables wastes:

Although interest in fiber as a food ingredient has waned in recent years, the importance of fiber cannot be overlooked. The health benefits coupled with functional properties such as water and fat holding capacity 
properties have created a renewed interest in fiber, particularly in the nutraceutical industry. Many of the fiber supplements which have been researched are obtained from by-products resulting from the processing of fruits and vegetables. Increased use of fiber supplementation would therefore not only improve the health benefits and functional properties of many foods. Data in Table (2) represent the proximate chemical composition of fruits and vegetables wastes, the results are in agreement with those obtained by Sosulski and Wu (1988); Camire and Flint (1991); Ralet et al. (1993); Camire et al., (1997) and Chantaro et al. (2008).

Table (2):Proximate chemical composition of used fruits and vegetables wastes.

\begin{tabular}{|l|c|c|c|c|}
\hline \multirow{2}{*}{ Components } & \multicolumn{4}{|c|}{ dietary fibers source } \\
\cline { 2 - 5 } & $\begin{array}{c}\text { Orange } \\
\text { waste }\end{array}$ & $\begin{array}{c}\text { Carrot } \\
\text { pomace }\end{array}$ & $\begin{array}{c}\text { Potato } \\
\text { peels }\end{array}$ & $\begin{array}{c}\text { Green pea } \\
\text { peels }\end{array}$ \\
\hline Moisture (\%) & $4.15 \pm 0.32$ & $4.61 \pm 0.21$ & $3.58 \pm 0.63$ & $4.28 \pm 0.27$ \\
\hline Total ash (\%) & $10.03 \pm 0.54$ & $7.29 \pm 0.32$ & $6.92 \pm 0.27$ & $7.18 \pm 0.34$ \\
\hline Total fat (\%) & $1.57 \pm 0.02$ & $1.75 \pm 0.01$ & $2.25 \pm 0.08$ & $1.34 \pm 0.03$ \\
\hline Total protein (\%) & $8.72 \pm 0.36$ & $10.06 \pm 0.18$ & $12.16 \pm 0.48$ & $13.27 \pm 0.51$ \\
\hline Total dietary fiber (\%) & 63.45 & 69.85 & 73.25 & 71.30 \\
\hline Insoluble fiber (\%) & $41.17 \pm 1.28$ & $45.12 \pm 1.08$ & $53.39 \pm 0.94$ & $51.48 \pm 1.34$ \\
\hline Soluble fiber (\%) & $22.28 \pm 0.93$ & $24.73 \pm 1.22$ & $19.86 \pm 1.47$ & $19.82 \pm 1.36$ \\
\hline
\end{tabular}

\section{Functional properties:}

It is well known that the functional properties of dietary fibers have the greatest effect on their functions in foods and physiological action in the body El-Refai et al., 2006. The results of the functional properties of fruits and vegetables wastes are given in Table (3). The functional properties of plant fibre depend on the IDF/SDF ratio, structure of the plant polysaccharides and vegetables or fruits sources.

Table (3): Functional properties of used fruits and vegetables wastes

\begin{tabular}{|l|c|c|c|c|}
\hline \multirow{2}{*}{ Components } & \multicolumn{4}{|c|}{ dietary fibers source } \\
\cline { 2 - 5 } & $\begin{array}{c}\text { Orange } \\
\text { waste }\end{array}$ & $\begin{array}{c}\text { Carrot } \\
\text { pomace }\end{array}$ & $\begin{array}{c}\text { Potato } \\
\text { peels }\end{array}$ & $\begin{array}{c}\text { Green pea } \\
\text { peels }\end{array}$ \\
\hline $\begin{array}{l}\text { Water holding capacity (WHC) (g } \\
\text { water/g dry fiber source) }\end{array}$ & $16.39 \pm 0.47$ & $19.72 \pm 0.38$ & $15.62 \pm 0.67$ & $13.48 \pm 0.14$ \\
\hline Swelling capacity (SWC) & $20.74 \pm 0.62$ & $23.96 \pm 0.58$ & $16.27 \pm 0.38$ & $14.93 \pm 0.41$ \\
\hline $\begin{array}{l}\text { Oil holding capacity (OHC) (g } \\
\text { oil/g dry fiber source) }\end{array}$ & $1.27 \pm 0.01$ & $3.95 \pm 0.17$ & $8.63 \pm 0.48$ & $6.89 \pm 0.35$ \\
\hline
\end{tabular}

The water holding capacity (WHC) is the quantity of water that remains bound to the hydrated fiber following the application of an external force (pressure or centrifugation), It consists of the sum of bound water, hydrodynamic water and, mainly, physically trapped water (Raghavendra, et al., 2006 and Vazquez- Ovando et al., 2009). It is an important property of DF from both a physiological and technological point of view. Dietary fiber holds water by adsorption and absorption phenomena and some water is also retained outside the fiber matrix (free water). WHC depends on fiber 
processing, washing increases WHC probably due to the removal of sugars, and the chemical and physical structure: the water-holding capacity is related to the SDF content, and high levels of SDF produce a high WHC because soluble fibres, possess a higher WHC than cellulosic fibres. WHC of different dietary fiber sources; orange waste, carrot pomace, potato peels and green pea peels are presented in Table 3. Relatively high values of WHC were obtained compared with the values obtained with other agricultural byproducts including apple pomace and pear pomace (Grigelmo-Miguel and Martin-Belloso, 1999). The high WHC values were related to the soluble dietary fiber fraction and pectic substances contained in the peels might account for their high WHC in orange waste. High WHC was also previously reported for orange waste and carrot pomace. The water holding capacity of carrot pomace was higher than that of orange waste. The higher WHC for the samples under study because we used suitable drying temperature to prepare dietary fiber sources. The WHC was lower at a higher drying temperature; this might be due to the degradation of some soluble dietary fiber components, leading to the loss of ability to retain water in the sample. The values of WHC are 16.39, 19.72, 15.62 and13.48 for orange waste, carrot pomace, potato peels and green pea peels, respectively which are higher than those reported for others fibrous residues such as grape, mango, peach and tomato (7.8-9.4 g water/g product) (El-Refai et al., 2006), bambangans peel (11.6 g water/g product), apple pomace $(8.4 \mathrm{~g}$ water $/ \mathrm{g}$ product) (Sudha et al., 2007 and Hassan et al., 2011), and other dietary fiber products such as date paste (1.3 g water/g product) (Sanchez-Zapata et al., 2011) and similar with other dietary fiber products such as carrot peel (21.89 $\mathrm{g}$ water/g product) (Chantaro et al., 2008). The high WHC values could indicate a lightness improve of food products where they were added.

The SWC of carrot pomace are presented in Table (3). The results showed that DF powder from carrot pomace possessed high SWC. These values are of similar order with those of cauliflower fiber (Femenia et al., 1997), coconut fiber (Raghavendra et al., 2006) and carrot fiber (Chantaro et al., 2008) but higher than those reported for citrus residues (Figuerola et al., 2005). Blanching had a significant effect on the SWC. During blanching carrot, some components might be lost with water and the change of structural tissues might enhance the water uptake. However, the other fiber sources blanching step don't occurred. Furthermore, a very high correlation between the SWC and WHC was obtained at each dietary fiber sources. In addition to chemical compositions, some physical properties, such as structure, particle size, porosity, $\mathrm{pH}$, temperature, ionic strength, types of ions in solutions and density are important to the understanding of the deferent behaviors of samples during hydration.

The two hydration properties, SWC and WHC, which are mainly determined by the food content (like dietary fiber) have been shown to be closely related, oil-holding capacity $\mathrm{OHC}$ is another important property of food ingredients used in formulated food. The $(\mathrm{OHC})$ is also a technological property related to the chemical structure of the plant polysaccharides and depends on surface properties, overall charge density, thickness, and hydrophobic nature of the fiber particle (Figuerola et al., 2005; Carme et al., 
2007 and Fernandez-López et al., 2009); it is also related with the IDF content, particle size and drying, dehydration promotes a general decrease in fiber $\mathrm{OHC}$ compared with the fresh fiber. The fiber sources show an $\mathrm{OHC}$ of $1.27,3.95,8.63$ and $6.89 \mathrm{~g}$ oil/g dry fibre respectively. This is similar the OHC of orange by-products $(1.81 \mathrm{~g} \mathrm{oil} / \mathrm{g}$ fibre), lemon by-products $(6.60 \mathrm{~g}$ oil/g fiber) and tiger nut by-product (6.90 g oil/g fibre) (Lario et al., 2004; Figuerola et al., 2005 and Sanchez-Zapata et al., 2009). For this reason, foods added with potato peels or green pea peels will not retain high amounts of oil, both in the case that it will be added as ingredient in the food product, or in the case that it will be used for frying processes.

This suggested that the all fiber sources in this study would be able to stabilize food emulsions with a high percentage of fat. Basically, the mechanism of $\mathrm{OHC}$ is mainly due to the physical entrapment of oil by capillary attraction. Moreover, the hydrophobicity of proteins also plays a major role in fat absorption. Therefore, among the fiber sources samples, the variations in $\mathrm{OHC}$ may be partially due to the deferent proportions of polar side chains of the amino acids on the surfaces of their protein molecules. Furthermore, the OHC of fiber sources samples are also related to the particle size, overall charge density and hydrophilicnature of the individual particles. Similarly, the correlation between $\mathrm{OHC}$ and total amount of protein and TDF was very high. This implied that the $\mathrm{OHC}$ of the fiber sources samples might also depend on the total content of protein and TDF present.

Rheological properties:

Dough produced from blends of wheat flour $(72 \%)$ and different levels of dietary fibers (orange waste, carrot pomace, potato peels and green pea peels) were tested for rheological properties.

\section{Farinograph parameters of wheat flours dough blended with dried fibers} sources:

The effect of replacing wheat flour with different levels $(5,10,15$ and $20 \%$ ) of dried dietary fiber sources (orange waste, carrot pomace, potato peels and green pea peels) on mixing dough properties are presented in Table (4). Data in Table (4) shows the effect of blending fiber sources with wheat flour (72\%) on the farinograph parameters, i.e. water absorption, arrival time, dough development time, dough stability and dough weakening.

The results indicate that water absorption, arrival time and dough development time were increased due to the increase of wheat flour replacement levels. This might be due to the increase in the fiber level in dietary fiber sources blends. These results agree with those obtained by Abd El-Moniem and Yassen (1993); who reported that addition of fiber sources caused an increase in the water absorption of the produced dough. This may be due to higher water hydration capacity of fibers. Dough stability increased due to the increase of wheat flour replacement with dietary fiber sources. These results confirmed increased stability with those obtained by Doweidar (2001); who found that the addition of dietary fiber source (dry carrot and pectin). Also, reported that the addition of dietary carrot led to increase water absorption and stability. Degree of weakening decreased due to the increase replacement levels of wheat flour with dietary fiber sources, this might be due to increasing of fibrous materials, which contribute gluten net development. 
Table (4): Effect of dietary fibres sources addition at different levels to wheat flour on farinograph parameters of dough.

\begin{tabular}{|c|c|c|c|c|c|c|}
\hline \multirow[b]{2}{*}{$\begin{array}{l}\text { Dietary fiber } \\
\text { source }\end{array}$} & \multirow{2}{*}{\begin{tabular}{|c|}
$\begin{array}{c}\text { Replacement } \\
\text { levels }\end{array}$ \\
$(\%)$
\end{tabular}} & \multicolumn{5}{|c|}{ Farinograph parameters } \\
\hline & & $\begin{array}{c}\text { Water } \\
\text { absorption } \\
(\%)\end{array}$ & $\begin{array}{c}\text { Arrival } \\
\text { time } \\
\text { (min) }\end{array}$ & \begin{tabular}{|c|} 
Dough \\
$\begin{array}{c}\text { development } \\
\text { (min) }\end{array}$
\end{tabular} & $\begin{array}{l}\text { Dough } \\
\text { stability } \\
\text { (min) }\end{array}$ & $\begin{array}{c}\text { Degree of } \\
\text { weakening } \\
\text { (B.U.) }\end{array}$ \\
\hline Control & 0 & 61.50 & 1.50 & 2.75 & 6.00 & 95.25 \\
\hline \multirow{4}{*}{ Orange waste } & 5 & 67.40 & 1.75 & 3.30 & 6.40 & 80.25 \\
\hline & 10 & 68.10 & 2.30 & 4.25 & 6.85 & 75.25 \\
\hline & 15 & 70.90 & 3.00 & 5.50 & 7.25 & 69.75 \\
\hline & 20 & 72.45 & 4.10 & 6.00 & 7.70 & 54.00 \\
\hline \multirow{4}{*}{ Carrot pomace } & 5 & 63.30 & 1.90 & 3.20 & 6.40 & 83.80 \\
\hline & 10 & 65.15 & 2.30 & 3.90 & 6.90 & 77.50 \\
\hline & 15 & 68.95 & 2.90 & 4.30 & 7.30 & 69.90 \\
\hline & 20 & 71.95 & 3.80 & 5.10 & 7.95 & 57.80 \\
\hline \multirow{4}{*}{ Potato peels } & 5 & 63.50 & 1.85 & 3.10 & 6.80 & 83.40 \\
\hline & 10 & 65.95 & 2.25 & 3.75 & 7.45 & 69.00 \\
\hline & 15 & 67.55 & 2.55 & 4.25 & 8.25 & 57.20 \\
\hline & 20 & 69.85 & 2.90 & 4.60 & 9.10 & 47.95 \\
\hline \multirow{4}{*}{ Green pea peels } & 5 & 62.75 & 1.70 & 3.00 & 6.75 & 77.10 \\
\hline & 10 & 63.45 & 2.10 & 3.45 & 7.85 & 60.20 \\
\hline & 15 & 64.75 & 2.25 & 3.80 & 9.40 & 48.65 \\
\hline & 20 & 65.90 & 2.45 & 4.05 & 10.80 & 35.60 \\
\hline
\end{tabular}

Water absorption of the control (wheat flour $72 \%$ ext.) showed a value of $61.5 \mathrm{ml}$. While, wheat flour blended with different ratios of fibre sources, $5,10,15$ and $20 \%$ showed a gradual increase in parallel with fiber sources increasing, this may be due to the high fiber contents in fiber sources. Arrival time showed a time in min ranged between 1.30 to $4.10 \mathrm{~min}$.. Dough development time of blends with fiber sources at the ratios of 5, 10, 15 and $20 \%$ resulted in $(2.75$ to $6 \mathrm{~min})$. Dough stability showed its maximum value (10.8 min.), when the blend contained $20 \%$ dry green pea peels and $80 \%$ wheat flours $72 \%$ extraction followed by $20 \%$ dry potato peel and $80 \%$ wheat flours $72 \%$ extraction $(9.1 \mathrm{~min}$.). From the above mentioned data, it could be concluded that, the replacement of fiber sources at different ratios improved the gluten network and farinograph parameters of the wheat flour dough. From the aforementioned data, it could be concluded that blending with fiber sources had a good farinograph parameters.

Extensograph parameters of wheat flours dough ( $72 \%$ extraction) blended with dried fibre sources:

Data in Table (5) shows the effect of addition fiber sources (in ratios of $5,10,15$ and $20 \%$ ) with wheat flours (72\% extraction) dough on the extensograph parameters, i.e. extensibility $(E)$, resistance to extension $(R)$ and the ratio between them and also the energy. The results show that the resistance was 781.25 B.U. for the control sample (wheat flour $72 \%$ ext.), while it decreased with increasing the levels of fiber sources in prepared blends. Also, the resistance value of dough produced from blends of wheat flour $(72 \%$ ext.) with dry green pea peels or potato peels more than of dough produced from blends for wheat flours (72\% ext.) with orange waste or carrot pomace but both still decreased than the control sample with increasing the 
fiber sources ratio. Extensibility (E) showed a value of $157.5 \mathrm{~mm}$ for the control sample (wheat flour $72 \%$ ext.). Blending with fiber sources showed a slight decrease due to the dried fiber sources. The lowest extensibility value was recorded due to the blend containing $20 \%$ green pea peels. The ratio between resistances to extension of extensibility reflects the effect of blends on the elasticity of the produced dough. Concerning the energy, the control sample resulted in the highest value while, other treatments resulted in the following decreasing. From the above mentioned data, it could be concluded that addition of fibre sources had a good extensograph parameters like the control sample.

Table (5): Effect of dietary fibers sources addition at different levels to wheat flour on extensograms parameters of dough.

\begin{tabular}{|c|c|c|c|c|c|}
\hline \multirow{2}{*}{$\begin{array}{l}\text { Dietary fiber } \\
\text { source }\end{array}$} & \multirow{2}{*}{$\begin{array}{c}\begin{array}{c}\text { Replacement } \\
\text { levels }\end{array} \\
(\%)\end{array}$} & \multicolumn{4}{|c|}{ Extensograph parameters } \\
\hline & & $\begin{array}{c}\text { Resistance } \\
\text { to extension } \\
\text { (B.U.) }\end{array}$ & $\mid$\begin{tabular}{|c|} 
Extensibility \\
(m.m.)
\end{tabular} & $\begin{array}{c}\text { Proportional } \\
\text { number } \\
\text { (R/E) }\end{array}$ & $\begin{array}{l}\text { Energy } \\
\left(\mathrm{cm}^{2}\right)\end{array}$ \\
\hline Control & 0 & $\begin{array}{l}781.25 \\
\end{array}$ & 157.50 & 4.96 & 127.50 \\
\hline \multirow{4}{*}{ Orange waste } & 5 & 790.00 & & 5.90 & 113.75 \\
\hline & 10 & 786.85 & 125.00 & 6.29 & 105.00 \\
\hline & 15 & 748.95 & 113.80 & 6.58 & 101.50 \\
\hline & 20 & 691.10 & 108.30 & 6.38 & 96.00 \\
\hline \multirow{4}{*}{ Carrot pomace } & 5 & 729.50 & & 4.72 & 125.20 \\
\hline & 10 & 715.35 & 145.05 & 4.93 & 115.80 \\
\hline & 15 & 683.20 & & 5.12 & 106.40 \\
\hline & 20 & 675.00 & 125 & 5.37 & 99.30 \\
\hline \multirow{4}{*}{ Potato peels } & 5 & 795 & & 6.17 & 119.40 \\
\hline & 10 & 742.45 & 121.45 & 6.11 & 107.95 \\
\hline & 15 & 695.50 & 116.35 & 5.98 & 98.65 \\
\hline & 20 & 639.00 & & 5.81 & 90.80 \\
\hline \multirow{4}{*}{$\begin{array}{l}\text { Green pea } \\
\text { peels }\end{array}$} & 5 & 840.05 & 113.50 & 7.40 & 118.95 \\
\hline & 10 & 808.35 & 103.00 & 7.85 & 111.00 \\
\hline & 15 & 783.50 & 90.55 & 8.65 & 103.95 \\
\hline & 20 & 744.70 & 82.80 & 8.99 & 93.45 \\
\hline
\end{tabular}

Effect of addition dietary fiber sources on texture characteristics of cakes substituted by different levels fiber:

The results presented in Table (6) show the texture characteristics (mechanical properties) of cake contained different types of fiber source, firmness must be explained by the different chemical interactions between oil, protein starch and fibre that affect its retrogradation, the interactions between the swollen starch granules, fibre and the protein network actively contribute to crumb firming, the results showed increased of cake firmness, with the exception of control cake sample. Cake contained the different levels of the dietary fiber sources led to the hardest with firmness higher than that of the control cake sample. Fiber can provoke a crumb firmness increase probably due to the thickening of the crumb cells surrounding the air spaces. Also firmness was increase may be a result of molecular entanglements between fiber and gluten proteins (Gomez et al., 2007). 
Table (6): Effect of addition dietary fiber sources on texture characteristics of cakes substituted by different levels of fibers

\begin{tabular}{|c|c|c|c|c|c|}
\hline \multirow[b]{2}{*}{ Characteristics } & \multirow{2}{*}{$\begin{array}{c}\text { Replacement } \\
\text { levels (\%) }\end{array}$} & \multicolumn{4}{|c|}{ Dietary fiber sources } \\
\hline & & $\begin{array}{c}\begin{array}{c}\text { Orange } \\
\text { waste }\end{array} \\
\end{array}$ & $\begin{array}{c}\text { Carrot } \\
\text { pomace }\end{array}$ & $\begin{array}{c}\text { Potato } \\
\text { peels }\end{array}$ & \begin{tabular}{|c}
$\begin{array}{c}\text { Green pea } \\
\text { peels }\end{array}$ \\
\end{tabular} \\
\hline \multirow{5}{*}{ Firmness } & 0 (Control) & 8.905 & 8.905 & 8.905 & 8.905 \\
\hline & 5 & 9.736 & 10.331 & 9.792 & 10.277 \\
\hline & 10 & 11.629 & 12.035 & 10.720 & 13.056 \\
\hline & 15 & 13.681 & 14.168 & 12.297 & 15.641 \\
\hline & 20 & 16.751 & 16.738 & 14.638 & 17.356 \\
\hline \multirow{5}{*}{ Cohesiveness } & 0 (Control) & 0.683 & 0.683 & 0.683 & 0.683 \\
\hline & 5 & 0.602 & 0.581 & 0.521 & 0.624 \\
\hline & 10 & 0.492 & 0.346 & 0.453 & 0.537 \\
\hline & 15 & 0.308 & 0.292 & 0.258 & 0.395 \\
\hline & 20 & 0.239 & 0.207 & 0.171 & 0.311 \\
\hline \multirow{5}{*}{ Gumminess } & 0 (Control) & 2.894 & 2.894 & 2.894 & 2.894 \\
\hline & 5 & 3.132 & 3.028 & 2.947 & 3.354 \\
\hline & 10 & 3.538 & 3.387 & 3.205 & 3.725 \\
\hline & 15 & 3.892 & 3.897 & 3.439 & 3.962 \\
\hline & 20 & 3.984 & 3.972 & 3.620 & 4.108 \\
\hline \multirow{5}{*}{ Chewiness } & 0 (Control) & 2.963 & 2.963 & 2.963 & 2.963 \\
\hline & 5 & 2.985 & 3.025 & 2.974 & 3.342 \\
\hline & 10 & 3.129 & 3.195 & 3.047 & 3.649 \\
\hline & 15 & 3.367 & 3.408 & 3.115 & 3.803 \\
\hline & 20 & 3.658 & 3.827 & 3.248 & 3.958 \\
\hline \multirow{5}{*}{ Springiness } & 0 (Control) & 0.742 & 0.742 & 0.742 & 0.742 \\
\hline & 5 & 0.692 & 0.655 & 0.673 & 0.718 \\
\hline & 10 & 0.583 & 0.525 & 0.534 & 0.634 \\
\hline & 15 & 0.490 & 0.497 & 0.468 & 0.587 \\
\hline & 20 & 0.405 & 0.378 & 0.361 & 0.435 \\
\hline \multirow{5}{*}{ Resillience } & 0 (Control) & 0.697 & 0.697 & 0.697 & 0.697 \\
\hline & 5 & 0.612 & 0.607 & 0.530 & 0.581 \\
\hline & 10 & 0.542 & 0.510 & 0.401 & 0.421 \\
\hline & 15 & 0.421 & 0.383 & 0.252 & 0.382 \\
\hline & 20 & 0.310 & 0.306 & 0.197 & 0.285 \\
\hline
\end{tabular}

An increase in chewiness and gumminess values with ageing was observed in all recipes. Chewiness is one of the texture parameters easily correlated with sensory evaluation through trained panels (Esteller et al., 2004). Both, gumminess and chewiness are parameters dependant on firmness. Therefore, their values followed a similar trend than that of firmness. Cohesiveness quantifies the internal resistance of food structure. As happened with firmness, cake cohesiveness depended on the addition of fiber. A similar result was also obtained in other baked goods (Esteller et al., 2004). A subjective evaluation of springiness is normally made by consumers and consists of slightly pressing the piece of food, by hand or with the mouth, and verifying how easily it returns to the original size. Finally, the addition of dietary fiber sources to wheat flour to produced cake improved the texture properties of cake due to high water holding capacity of fibre, these results 
are in agree with many researchers which have shown in their studies that remarkable the lack of any clear relationship between cake water contents and its firmness. Decreased crumb firmness did not improve crumb texture, which showed increased crumbliness.

\section{Effect of addition types of dietary fiber source on hardness measurement (mechanical properties) of cake}

Data listed in Table (7) show the effect of addition different types of fiber sources with wheat flour $(72 \%)$ to produced cake on compression properties (hardness measurement). The results show that, all additions were increase hardness by increasing addition levels comparing with control sample. The results in the same table showed that, the addition fiber sources to produced cakes improved the hardness due to the effect of fibers, the fibers' function had high adsorption capacity of oil and water and therefore the hardness increased with adding fibers. These results agree with Sowmya et al. (2009). The hardness of the cake ranged from 0.524 to 0.820 for control sample and the addition of $20 \%$ green pea peels sample, respectively. The above results indicated that the addition of types of fiber sources is beneficial in improving the maximum force and texture.

Table (7): Effect of addition dietary fiber sources on hardness measurement (mechanical properties) of cakes

\begin{tabular}{|c|c|c|c|c|}
\hline \multirow{2}{*}{$\begin{array}{c}\text { Dietary fiber } \\
\text { sources }\end{array}$} & $\begin{array}{c}\text { Substituted } \\
\text { levels }\end{array}$ & $\begin{array}{c}\text { Maximum } \\
\text { Force }\end{array}$ & $\begin{array}{c}\text { Maximum } \\
\text { deformation }\end{array}$ & Hardness \\
\cline { 2 - 5 } & $\mathbf{( \% )}$ & $\mathbf{N}$ & $\mathbf{m m}$ & $\mathbf{N} / \mathbf{m m}$ \\
\hline Control & $\mathbf{0}$ & 26.22 & 50 & 0.524 \\
\hline \multirow{4}{*}{$\begin{array}{c}\text { Orange } \\
\text { waste }\end{array}$} & $\mathbf{5}$ & 28.37 & 50 & 0.567 \\
\cline { 2 - 5 } & $\mathbf{1 0}$ & 30.04 & 50 & 0.601 \\
\cline { 2 - 5 } & $\mathbf{1 5}$ & 33.31 & 50 & 0.666 \\
\hline \multirow{4}{*}{ Carrot pomace } & $\mathbf{2 0}$ & 36.94 & 50 & 0.739 \\
\cline { 2 - 5 } & $\mathbf{5}$ & 28.49 & 50 & 0.570 \\
\cline { 2 - 5 } & $\mathbf{1 0}$ & 31.06 & 50 & 0.621 \\
\cline { 2 - 5 } & $\mathbf{1 5}$ & 34.23 & 50 & 0.685 \\
\cline { 2 - 5 } & $\mathbf{2 0}$ & 37.60 & 50 & 0.752 \\
\cline { 2 - 5 } & $\mathbf{5}$ & 28.84 & 50 & 0.577 \\
\cline { 2 - 5 } & $\mathbf{1 0}$ & 30.89 & 50 & 0.618 \\
\hline \multirow{3}{*}{$\begin{array}{c}\text { Potato peels } \\
\text { peels }\end{array}$} & $\mathbf{2 0}$ & 32.31 & 50 & 0.646 \\
\cline { 2 - 5 } & $\mathbf{5}$ & 34.95 & 50 & 0.699 \\
\cline { 2 - 5 } & $\mathbf{1 0}$ & 35.43 & 50 & 0.709 \\
\hline
\end{tabular}

Sensory evaluation of fiber substituted cakes at deferent levels.

The sensory evaluation of produced high fiber cake samples were evaluated. Twelve trained sensory panelists evaluated the products under investigation for their uniformity, size of cells, thickness, grain, moistness, tenderness, softness, crumb color, flavor and overall acceptability. The mean values were statistically analyzed using analysis of variance and least significant difference (LSD). In general, cake samples were significantly 
different from control sample for all sensory properties. The results indicated that, the replacement of wheat flour caused a significant decrease in cake properties scores. The results in Table (8) showed that all high fiber substituted cake samples were significantly lower than control cake sample in all sensory characteristics. significant differences $(P>0.05)$ in uniformity, size of cells, thickness, grain, moistness, tenderness, softness, crumb color, flavor and overall acceptability characteristics with control cake sample.

Table (8): Effect of addition dietary fibers sources on sensory attributes of produced cakes (mean $\pm S D$ ).

\begin{tabular}{|c|c|c|c|c|c|c|c|c|c|c|c|}
\hline \multirow[b]{2}{*}{$\begin{array}{c}\text { Dietary } \\
\text { fiber } \\
\text { sources }\end{array}$} & \multirow[b]{2}{*}{$\begin{array}{l}\text { Substi } \\
\text { tuted } \\
\text { levels }\end{array}$} & \multicolumn{10}{|c|}{ Sensory attributes } \\
\hline & & $\begin{array}{c}\text { Unifor } \\
\text { mity } \\
(10)\end{array}$ & $\begin{array}{l}\text { Siz of } \\
\text { cells } \\
(10)\end{array}$ & $\begin{array}{c}\text { Thickn } \\
\text { ess } \\
(10)\end{array}$ & $\begin{array}{c}\text { Grain } \\
\text { (20) }\end{array}$ & $\begin{array}{c}\text { Moistn } \\
\text { ess } \\
(10)\end{array}$ & $\begin{array}{c}\text { Tende } \\
\text { rness } \\
(10)\end{array}$ & $\begin{array}{c}\text { Softne } \\
\text { ss } \\
(10)\end{array}$ & $\begin{array}{c}\text { Crumb } \\
\text { color } \\
(10)\end{array}$ & $\mid \begin{array}{c}\text { Flavor } \\
(10)\end{array}$ & $\begin{array}{c}\text { Overall } \\
\text { accepta } \\
\text { bility } \\
(100)\end{array}$ \\
\hline Control & 0 & $\begin{array}{l}9.65^{\mathrm{a}} \\
\pm 0.19 \\
\end{array}$ & $\begin{array}{l}9.10^{\mathrm{ab}} \\
\pm 0.10\end{array}$ & \begin{tabular}{|l|}
$9.75^{\mathrm{a}}$ \\
\pm 0.47
\end{tabular} & $\begin{array}{c}19.60^{a} \\
\pm 0.29\end{array}$ & $\begin{array}{l}9.45^{\mathrm{ab}} \\
\pm 0.13\end{array}$ & \begin{tabular}{|l|}
$9.60^{\mathrm{a}}$ \\
\pm 0.11 \\
\end{tabular} & $\begin{array}{l}9.70^{a} \\
\pm 0.30\end{array}$ & \begin{tabular}{|c|}
$9.30^{\mathrm{ab}}$ \\
\pm 0.18
\end{tabular} & $\begin{array}{l}9.75^{a} \\
\pm 0.16\end{array}$ & $\begin{array}{c}97.65^{\mathrm{ab}} \\
\pm 1.95\end{array}$ \\
\hline \multirow{4}{*}{$\begin{array}{c}\text { Orange } \\
\text { waste }\end{array}$} & 5 & $\begin{array}{l}9.60^{a} \\
\pm 0.28 \\
\end{array}$ & $\begin{array}{l}9.00^{\mathrm{ab}} \\
\pm 0.14 \\
\end{array}$ & $\begin{array}{l}9.50^{\mathrm{ab}} \\
\pm 0.14 \\
\end{array}$ & $\begin{array}{c}19.10^{\mathrm{ab}} \\
\pm 0.26\end{array}$ & $\begin{array}{l}9.10^{\mathrm{ab}} \\
\pm 0.15\end{array}$ & $\begin{array}{l}9.20^{\mathrm{ab}} \\
\pm 0.18 \\
\end{array}$ & $\begin{array}{l}9.70^{a} \\
\pm 0.20\end{array}$ & $\begin{array}{l}9.40^{\mathrm{ab}} \\
\pm 0.16 \\
\end{array}$ & $\begin{array}{l}9.30^{\mathrm{ab}} \\
\pm 0.18\end{array}$ & $\begin{array}{c}97.20^{\mathrm{ab}} \\
\pm 1.55\end{array}$ \\
\hline & 10 & $\begin{array}{l}9.05^{\mathrm{ab}} \\
\pm 0.21\end{array}$ & $\begin{array}{l}8.90^{a b} \\
\pm 0.20\end{array}$ & $\begin{array}{l}9.10^{a b} \\
\pm 0.36\end{array}$ & $\begin{array}{c}18.80^{\mathrm{ab}} \\
\pm 0.28\end{array}$ & $\begin{array}{l}8.95^{\mathrm{ab}} \\
\pm 0.21\end{array}$ & $\begin{array}{l}8.95^{\mathrm{ab}} \\
\pm 0.18\end{array}$ & $\begin{array}{l}9.35^{\mathrm{ab}} \\
\pm 0.21\end{array}$ & $\begin{array}{l}9.15^{\mathrm{ab}} \\
\pm 0.25\end{array}$ & $\begin{array}{l}8.95^{\mathrm{ab}} \\
\pm 0.27\end{array}$ & $\begin{array}{c}96.40^{\mathrm{ab}} \\
\pm 1.88\end{array}$ \\
\hline & 15 & $\begin{array}{l}8.75^{\mathrm{bc}} \\
\pm 0.09\end{array}$ & $\begin{array}{l}8.75^{\mathrm{ab}} \\
\pm 0.24\end{array}$ & $\begin{array}{l}8.85^{b} \\
\pm 0.17\end{array}$ & $\begin{array}{c}18.40^{\mathrm{ab}} \\
\pm 0.48\end{array}$ & $\begin{array}{l}8.60^{\mathrm{b}} \\
\pm 0.27\end{array}$ & $\begin{array}{l}8.70^{\mathrm{b}} \\
\pm 0.15\end{array}$ & $\begin{array}{l}8.90^{\mathrm{ab}} \\
\pm 0.32\end{array}$ & $\begin{array}{c}8.85^{\mathrm{ab}} \\
\pm 0.35\end{array}$ & $\begin{array}{c}8.80^{\mathrm{ab}} \\
\pm 0.13\end{array}$ & $\begin{array}{c}93.60^{b c} \\
\pm 1.92\end{array}$ \\
\hline & 20 & $\begin{array}{l}7.80^{c} \\
\pm 0.44\end{array}$ & $\begin{array}{l}7.85^{b c} \\
\pm 0.32\end{array}$ & $\begin{array}{l}7.95^{c} \\
\pm 0.21\end{array}$ & $\begin{array}{c}17.60^{\text {bc }} \\
\pm 0.27\end{array}$ & $\begin{array}{l}7.80^{b c} \\
\pm 0.22\end{array}$ & \begin{tabular}{|l|}
$7.70^{c}$ \\
$\pm 0.41^{2}$
\end{tabular} & $\begin{array}{l}7.70^{\mathrm{bc}} \\
\pm 0.21\end{array}$ & \begin{tabular}{|l|}
$7.60^{\mathrm{b}}$ \\
\pm 0.26
\end{tabular} & $\begin{array}{c}7.80 \mathrm{bc} \\
\pm 0.21\end{array}$ & $\begin{array}{c}88.90^{\mathrm{cd}} \\
\pm 2.02\end{array}$ \\
\hline \multirow{4}{*}{$\begin{array}{c}\text { Carrot } \\
\text { pomace }\end{array}$} & 5 & $\begin{array}{l}9.50^{a b} \\
\pm 0.41\end{array}$ & $\begin{array}{l}9.30^{a} \\
\pm 0.71\end{array}$ & $\begin{array}{l}9.45^{\mathrm{ab}} \\
\pm 0.40\end{array}$ & $\begin{array}{c}19.20^{\mathrm{ab}} \\
\pm 0.20\end{array}$ & \begin{tabular}{|l|}
$9.70^{a}$ \\
\pm 0.84
\end{tabular} & $\begin{array}{l}9.40^{\mathrm{ab}} \\
\pm 0.32\end{array}$ & $\begin{array}{l}9.45^{\mathrm{a}} \\
\pm 0.52\end{array}$ & \begin{tabular}{|l|}
$9.65^{\mathrm{a}}$ \\
\pm 0.42
\end{tabular} & $\begin{array}{l}9.65^{\mathrm{ab}} \\
\pm 0.33\end{array}$ & $\begin{array}{c}97.95^{\mathrm{a}} \\
\pm 2.42\end{array}$ \\
\hline & 10 & $\begin{array}{l}9.05^{\mathrm{ab}} \\
\pm 0.37 \\
\end{array}$ & $\begin{array}{l}9.00^{\mathrm{ab}} \\
\pm 0.47 \\
\end{array}$ & $\begin{array}{l}9.10^{a b} \\
\pm 0.38\end{array}$ & $\begin{array}{c}18.80^{\mathrm{ab}} \\
\pm 0.39\end{array}$ & $\begin{array}{l}9.15^{\mathrm{ab}} \\
\pm 0.72\end{array}$ & $\begin{array}{c}9.00 \mathrm{ab} \\
\pm 0.36\end{array}$ & $\begin{array}{l}9.05^{\mathrm{ab}} \\
\pm 0.79\end{array}$ & $\begin{array}{l}9.05^{\mathrm{ab}} \\
\pm 0.62 \\
\end{array}$ & $\begin{array}{l}8.75^{\mathrm{ab}} \\
\pm 0.31\end{array}$ & $\begin{array}{c}93.35 \text { bc } \\
\pm 2.27\end{array}$ \\
\hline & 15 & $\begin{array}{c}8.15^{\mathrm{bc} 9} \\
\pm 0.28\end{array}$ & $\begin{array}{l}8.20^{\mathrm{b}} \\
\pm 0.41\end{array}$ & $\begin{array}{l}8.15^{b} \\
\pm 0.34\end{array}$ & $\begin{array}{l}18.00^{\mathrm{b}} \\
\pm 0.40\end{array}$ & $\begin{array}{l}8.20^{\mathrm{bc}} \\
\pm 0.37\end{array}$ & $\begin{array}{l}8.10^{\mathrm{bc}} \\
\pm 0.32\end{array}$ & $\begin{array}{l}8.40^{\mathrm{b}} \\
\pm 0.32\end{array}$ & \begin{tabular}{|l|}
$8.55^{b}$ \\
\pm 0.91
\end{tabular} & $\begin{array}{l}8.60^{\mathrm{b}} \\
\pm 0.34\end{array}$ & $\begin{array}{c}90.30^{\mathrm{c}} \\
\pm 2.35\end{array}$ \\
\hline & 20 & $\begin{array}{l}7.10^{\text {cd }} \\
\pm 0.38\end{array}$ & $\begin{array}{l}7.60^{b c} \\
\pm 0.65\end{array}$ & $\begin{array}{l}7.45^{c} \\
\pm 0.57\end{array}$ & $\begin{array}{c}17.10^{\mathrm{bc}} \\
\pm 0.41\end{array}$ & $\begin{array}{l}7.55^{\circ} \\
\pm 0.32\end{array}$ & $\begin{array}{l}7.40^{\mathrm{cd}} \\
\pm 0.39 \\
\end{array}$ & $\begin{array}{l}7.50^{\mathrm{bc}} \\
\pm 0.67\end{array}$ & \begin{tabular}{|l|}
$7.45^{c}$ \\
\pm 0.29 \\
\end{tabular} & $\begin{array}{l}7.25^{c} \\
\pm 0.47\end{array}$ & $\begin{array}{c}86.35^{\mathrm{d}} \\
\pm 2.13^{-1}\end{array}$ \\
\hline \multirow{4}{*}{$\begin{array}{c}\text { Potato } \\
\text { peels }\end{array}$} & 5 & $\begin{array}{l}9.05^{\mathrm{ab}} \\
\pm 0.27 \\
\end{array}$ & $\begin{array}{l}8.65^{\mathrm{ab}} \\
\pm 0.38 \\
\end{array}$ & $\begin{array}{l}9.05^{\mathrm{ab}} \\
\pm 0.42 \\
\end{array}$ & $\begin{array}{l}18.10^{\mathrm{b}} \\
\pm 0.22 \\
\end{array}$ & $\begin{array}{l}9.00^{\mathrm{ab}} \\
\pm 0.51\end{array}$ & $\begin{array}{l}9.10^{\mathrm{ab}} \\
\pm 0.48\end{array}$ & $\begin{array}{l}8.75^{\mathrm{ab}} \\
\pm 0.37\end{array}$ & $\begin{array}{l}8.40^{\mathrm{b}} \\
\pm 0.58\end{array}$ & $\begin{array}{l}9.10^{\mathrm{ab}} \\
\pm 0.34\end{array}$ & $\begin{array}{c}95.15^{\mathrm{ab}} \\
\pm 2.55\end{array}$ \\
\hline & 10 & $\begin{array}{l}8.50^{\mathrm{bc}} \\
\pm 0.24\end{array}$ & $\begin{array}{l}8.00^{\mathrm{bc}} \\
\pm 0.38\end{array}$ & $\begin{array}{l}8.40^{\mathrm{b}} \\
\pm 0.44\end{array}$ & $\begin{array}{c}17.60^{\mathrm{bc}} \\
\pm 0.21\end{array}$ & $\begin{array}{l}8.10^{\mathrm{bc}} \\
\pm 0.19\end{array}$ & $\begin{array}{c}8.20 \text { bc } \\
\pm 0.12\end{array}$ & $\begin{array}{l}8.10^{\mathrm{bc}} \\
\pm 0.50\end{array}$ & \begin{tabular}{|l|}
$8.10^{\mathrm{b}}$ \\
\pm 0.10
\end{tabular} & $\begin{array}{l}8.30^{\mathrm{bc}} \\
\pm 0.64\end{array}$ & $\begin{array}{c}88.90^{\mathrm{cd}} \\
\pm 2.02\end{array}$ \\
\hline & 15 & $\begin{array}{l}7.45^{\mathrm{cd}} \\
\pm 0.45\end{array}$ & $\begin{array}{l}7.60^{b c} \\
\pm 0.34\end{array}$ & $\begin{array}{l}7.55^{c} \\
\pm 0.29\end{array}$ & $\begin{array}{l}16.40^{\mathrm{c}} \\
\pm 0.28\end{array}$ & $\begin{array}{l}7.50^{\mathrm{c}} \\
\pm 0.31\end{array}$ & $\begin{array}{c}7.40^{\mathrm{cd}} \\
\pm 0.54\end{array}$ & $\begin{array}{l}7.20^{c} \\
\pm 0.37\end{array}$ & $\begin{array}{l}7.40^{c} \\
\pm 0.38\end{array}$ & $\begin{array}{l}7.20^{\mathrm{c}} \\
\pm 0.67\end{array}$ & $\begin{array}{c}81.80^{\mathrm{e}} \\
\pm 2.46\end{array}$ \\
\hline & 20 & $\begin{array}{l}6.30^{d} \\
\pm 0.63\end{array}$ & $\begin{array}{l}6.20^{d} \\
\pm 0.34\end{array}$ & $\begin{array}{l}6.60^{d} \\
\pm 0.43\end{array}$ & $\begin{array}{c}15.70^{\mathrm{c}} \\
\pm 0.53\end{array}$ & $\begin{array}{l}6.40^{d} \\
\pm 0.53\end{array}$ & \begin{tabular}{|l|}
$6.80^{d}$ \\
$\pm 0.64^{-1}$ \\
\end{tabular} & $\begin{array}{l}6.40^{c} \\
\pm 0.52\end{array}$ & $\begin{array}{l}6.60^{\circ} \\
\pm 0.59 \\
\end{array}$ & $\begin{array}{l}6.45^{\mathrm{c}} \\
\pm 0.56\end{array}$ & $\begin{array}{c}79.50^{\mathrm{e}} \\
\pm 2.76\end{array}$ \\
\hline \multirow{4}{*}{$\begin{array}{c}\text { Green } \\
\text { pea } \\
\text { peels }\end{array}$} & 5 & $\begin{array}{l}9.10^{\mathrm{ab}} \\
\pm 0.24\end{array}$ & $\begin{array}{l}9.00^{\mathrm{ab}} \\
\pm 0.48\end{array}$ & $\begin{array}{l}9.70^{a} \\
\pm 0.22\end{array}$ & $\begin{array}{c}19.10^{\mathrm{ab}} \\
\pm 0.28\end{array}$ & $\begin{array}{l}9.25^{\mathrm{a}} \\
\pm 0.32\end{array}$ & $\begin{array}{l}9.00^{\mathrm{ab}} \\
\pm 0.41\end{array}$ & $\begin{array}{l}9.25^{\mathrm{ab}} \\
\pm 0.35\end{array}$ & $\begin{array}{c}9.10^{\mathrm{ab}} \\
\pm 0.58\end{array}$ & $\begin{array}{l}9.15^{\mathrm{ab}} \\
\pm 0.29\end{array}$ & $\begin{array}{c}94.10^{\mathrm{b}} \\
\pm 1.99\end{array}$ \\
\hline & 10 & $\begin{array}{l}8.25^{\mathrm{bc}} \\
\pm 0.55\end{array}$ & $\begin{array}{l}8.40^{a b} \\
\pm 0.62\end{array}$ & $\begin{array}{l}8.10^{\mathrm{b}} \\
\pm 0.45\end{array}$ & $\begin{array}{c}17.40^{\mathrm{bc}} \\
\pm 0.51\end{array}$ & $\begin{array}{l}8.10^{\mathrm{bc}} \\
\pm 0.28\end{array}$ & $\begin{array}{l}8.20^{\mathrm{bc}} \\
\pm 0.39\end{array}$ & $\begin{array}{l}8.40^{\mathrm{b}} \\
\pm 0.17\end{array}$ & $\begin{array}{l}8.50^{\mathrm{b}} \\
\pm 0.28\end{array}$ & $\begin{array}{l}8.40^{b c} \\
\pm 0.24\end{array}$ & $\begin{array}{c}89.45^{\mathrm{cd}} \\
\pm 2.88\end{array}$ \\
\hline & 15 & $\begin{array}{l}7.00^{\mathrm{d}} \\
\pm 0.61\end{array}$ & \begin{tabular}{|l|}
$7.20^{\circ}$ \\
\pm 0.33
\end{tabular} & $\begin{array}{l}7.60^{\mathrm{c}} \\
\pm 0.40\end{array}$ & $\begin{array}{c}16.30^{c} \\
\pm 0.63\end{array}$ & $\begin{array}{l}7.30^{\circ} \\
\pm 0.51\end{array}$ & $\begin{array}{c}7.50^{\text {cd }} \\
\pm 0.60\end{array}$ & $\begin{array}{c}7.50^{\mathrm{bc}} \\
\pm 0.58\end{array}$ & \begin{tabular}{|l|}
$7.45^{\mathrm{c}}$ \\
\pm 0.51
\end{tabular} & $\begin{array}{l}7.45^{c} \\
\pm 0.71\end{array}$ & $\begin{array}{c}84.75 \text { de } \\
\pm 2.85\end{array}$ \\
\hline & 20 & $\begin{array}{l}6.85^{d} \\
\pm 0.68\end{array}$ & $\begin{array}{l}7.00^{\mathrm{cd}} \\
\pm 0.61\end{array}$ & $\begin{array}{l}7.10^{d} \\
\pm 0.24\end{array}$ & $\begin{array}{l}15.20^{\mathrm{c}} \\
\pm 0.24\end{array}$ & $\begin{array}{l}6.90^{\mathrm{cd}} \\
\pm 0.32\end{array}$ & $\begin{array}{l}6.95^{\mathrm{cd}} \\
\pm 0.34\end{array}$ & $\begin{array}{l}7.00^{c} \\
\pm 0.40\end{array}$ & $\begin{array}{l}6.95^{c} \\
\pm 0.39\end{array}$ & $\begin{array}{l}7.05^{\mathrm{c}} \\
\pm 0.30\end{array}$ & $\begin{array}{c}81.90^{\mathrm{e}} \\
\pm 2.46\end{array}$ \\
\hline \multicolumn{2}{|c|}{ L.S.D at $P<0.05$} & 0.79 & 0.91 & 0.84 & 1.43 & 0.86 & 0.89 & 1.02 & 1.07 & 1.14 & 3.72 \\
\hline
\end{tabular}

${ }_{a, b}$ There is no significant different $(P>0.05)$ between any two means, within the same attribute have the same letter

The results indicated that replacement of fiber with wheat flour substitutes caused a significant decrease in cake properties. However, there 
were significant differences between cake samples containing the same type of fiber source at $5,10,15$ and $20 \%$ replacement levels. The highest score in the same type of fiber source for all attributes were that achieved by cake samples with fiber source at $5 \%$ replacement level. On the other hand, the lowest scores in the same type of fiber source for all attributes were that achieved by cake samples with fiber source at $20 \%$ replacement level. For overall acceptability. Also for the all sensory attributes the cake samples at $0 \%$ substitution level (cake control) had the highest score, followed by $5 \%$ substitution level of all treatments for all attributes, then $10 \%$ substitution level for every type of fiber sources in all sensory characteristics. The cake samples at $20 \%$ substitution level had the lowest score. Samples prepared by using orange waste and carrot pomace had a slight higher score, but the lowest score were for samples prepared by potato and green pea peels. The above results are in agreement with those obtained by Doweidar (2001); ElHadidi (2006) and Saeed (2010) who reported that statistical analysis of sensory evaluation of the control cakes versus cakes containing some fibre powders showed insignificant differences.

\section{Effect of addition dietary fiber sources on physical properties of produced cakes:}

Data presented in Table (9) show that, the addition of dietary fiber sources was increased volume of cake under investigation, From this results indicated the important of adding dietary fiber sources on the volume of cake. Also, addition of dietary fiber sources was increased specific volume. The trend of increasing in the specific volume was go high after adding dietary fiber sources. These results are in agreement with Saeed (2010).

Table (9): Effect of addition dietary fiber sources on physical properties of produced cake.

\begin{tabular}{|c|c|c|c|c|}
\hline Dietary fiber sources & $\begin{array}{l}\text { Substituted } \\
\text { levels (\%) }\end{array}$ & $\begin{array}{l}\text { Weight } \\
\text { (g) }\end{array}$ & $\begin{array}{c}\text { Volume } \\
\left(\mathrm{cm}^{3}\right)\end{array}$ & $\begin{array}{l}\text { Specific volume } \\
\left(\mathrm{cm}^{3}\right) / \mathrm{g}\end{array}$ \\
\hline $\begin{array}{c}\text { Control (Wheat flour } \\
72 \%)\end{array}$ & 0 & 454.95 & 1084.93 & 2.385 \\
\hline \multirow{4}{*}{ Orange waste } & 5 & 455.68 & 1174.52 & 2.578 \\
\hline & 10 & 456.91 & 1254.37 & 2.745 \\
\hline & 15 & 458.49 & 1343.85 & 2.931 \\
\hline & 20 & 461.12 & 1481.28 & 3.212 \\
\hline \multirow{4}{*}{ Carrot pomace } & 5 & 454.47 & 1127.58 & 2.481 \\
\hline & 10 & 456.69 & 1245.91 & 2.728 \\
\hline & 15 & 457.82 & 1289.07 & 2.816 \\
\hline & 20 & 458.37 & 1357.19 & 2.961 \\
\hline \multirow{4}{*}{ Potato peels } & 5 & 457.88 & 1097.57 & 2.397 \\
\hline & 10 & 461.45 & 1174.32 & 2.545 \\
\hline & 15 & 464.58 & 1203.85 & 2.591 \\
\hline & 20 & 469.37 & 1286.59 & 2.741 \\
\hline \multirow{4}{*}{ Green pea peels } & 5 & 452.18 & 1182.63 & 2.615 \\
\hline & 10 & 453.64 & 1257.37 & 2.772 \\
\hline & 15 & 452.87 & 1328.06 & 2.933 \\
\hline & 20 & 453.93 & 1391.24 & 3.065 \\
\hline
\end{tabular}




\section{CONCLUSIONS}

This study demonstrated the feasibility of using some food processing wastes to produce dietary fiber powders which may be used as a food ingredient. The results showed that the sources of dietary fiber had significant effects on the dietary fiber composition and technological properties. Moreover, the high effect on hydration properties which would affect the further application in real food system. Furthermore, carrot and orange fibers had high WHC and SWC values, which are good for food applications. Overall, the results suggested that orange waste, carrot pomace, potato peels and green pea peels could be used as a good raw material to produce dietary fiber powders. From industrial point of view, the fiber sources which are the residues from processing could be further processed to add value to the products in Egypt.

\section{Future trends}

Used new raw materials by-products, which containing a high amount of soluble and insoluble fractions of fibers and associated bioactive compounds. A good control of the parameters involved in this process (mainly in the washing and drying steps) could also be taken into account in order to minimize losses in the soluble dietary fiber components and in the biological activity of the associated compounds.

\section{Acknowledgement}

This research was partially funded by the Saudi Society for Food and Nutrition (SSFN). We thanks the Saudi Society for Food and Nutrition for this fund.

\section{REFERENCES}

A.A.C.C. (2000). Approved methods of American Association of Cereal Chemists $\left(10^{\text {th }}\right.$ ed.). published by American Association of Cereal Chemists, Ins. Saint Paul, Minnesota, USA.

Abd El-Moniem, G.M. and Yassen, A.A.E. (1993). High dietary fiber cookies from several sources of bran or husk. Egypt. J. Food. Sci., 21: 157-170.

A.O.A.C. (2000). Official Methods of Analysis (17 th $\mathrm{ed}$.). Arlington, VA: Association of Official Analytical Chemists, AOAC International.

Camire, M.E. and Flint, S.I. (1991) Thermal processing effects on dietary fiber composition and hydration capacity in corn meal, oat meal, and potato peels. Cereal Chem. 68: 645-647.

Camire, M.E.; Violette, D.; Dougherty, M.P. and McLaughlin, M.A. (1997) Potato peel dietary fiber composition: Effects of peeling and extrusion cooking processes. J Agric Food Chem., 45: 1404-1408.

Carle, R.; Keller, P.; Schieber, A.; Rentschler, C.; Katzschner, T.; Rauch, D.; et al. (2001). Method for obtaining useful materials from the byproducts of fruit and vegetable processing. Patent application, WO 01/78859 A1.

Carme, G.M.; Susana, S.; Carmen, R. and Antoni, F. (2007). Effect of air during temperature on physicochemical properties of dietary and 
antioxidant capacity of orange (Citrus aurantium v.Canoneta) byproducts. Food chemistry, 104: 1014-1024.

Chantaro, P.; Devahastin, S. and Chiewchan, N. (2008). Production of antioxidant high dietary fiber powder from carrot peels. LWT - Food Science and Technology 41, 1987-1994.

Chau, C. F., and Huang, Y. L. (2003). Comparison of the chemical composition and physicochemical properties of different fibers prepared from the peel of Citrus sinensis L. Cv. Liucheng. Journal of Agricultural and Food Chemistry, 51, 2615-2618.

Doweidar, M. M. (2001). Chemical and physical studies on some natural resources used in improving bakery products. Ph. D. Thesis, Fac. of Agric, Cairo Univ., Egypt.

El-Hadidi, S.T. (2006). Chemical and biological Evaluation of Cake products containing resistant starch and dietary fiber. Ph.D. Thesis, Fac. of Agric, Cairo Univ., Egypt.

El-Refai, A.A.; El-Bastawesy, A. and Zakaria, M.M. (2006). Evaluation of some food processing wastes as sources of dietary fibers. J. Agric. Sci. Mansoura Univ. 31: 6505-6515.

Esteller, M.S., Amaral, R.L. and Lannes, S.C. (2004). Effect of sugar and fat replacers on the texture of baked goods. J. Texture Studies, 35: 383393.

Femenia, A.; Lefebvre, C.; Thebaudin, Y.; Robertson, J. and Bourgeois, C. (1997). Physical and sensory properties of model foods supplemented with cauliflower fiber. Journal of Food Science, 62(4), 635-639.

Fernandez-Gines, J. M.; Fernadez-Lopez, J.; Sayas-Barbera, E. and PerezAlvarez, J. A. (2003). Effects of storage conditions on quality characteristics of bologna sausages made with citrus fiber. Journal of Food Science, 68(2), 710-715.

Fernandez-Lopez, J.; Sendra-Nadal, E.; Navarro, C.; Sayas, E.; ViudaMartos, M. and Pérez-Alvarez, J.A. (2009). Storage stability of a high dietary fibre powder from orange by-products. International Journal of Food Science and Technology 44, 748-756.

Figuerola, F.; Hurtado, M.L.; Estévez, A.M.; Chiffelle, I. and Asenjo, F. (2005). Fibre concentrates from apple pomace and citrus peel as potential fibre sources for food enrichment. Food Chemistry, 91, 395401.

Gallaher, D. and Schneeman, B.O. (2001). Dietary fiber. In: B. Bowman and R. Russel (Eds.). Present knowledge in nutrition ( $8^{\text {th }}$ ed., $805 p$ ). Washington, DC: ILSI.

Gomez, K.A. and Gomez, A.A. (1984). Statistical Procedures for Agriculture Research. John Wiliy and Sons Editor Inc. USA, 2 ed., Chapter 3,129184.

Gomez, M.; Ronda, F.; Coballera, A.P.; Blanco, A.C. and Rosell, C.M. (2007). Functionality of different hydrocolloids on the quality and shelf life of yellow layer cakes. Food Hydrocolloids, 21(2), 167-173.

Gorinstein, S.; Zachwieja, Z.; Folta, M.; Barton, H.; Piotrowicz, J.; Zember, M.; Weisz, M.; Trakhtenberg, S. and Martin-Belloso, O. (2001). Comparative content of dietary fiber, total phenolics, and minerals in 
persimmons and apples. Journal of Agricultural and Food Chemistry, 49, 952-957.

Grigelmo-Miguel, N. and Martin-Belloso, O. (1999). Influence of fruit dietary fiber addition on physical and sensorial properties of strawberry jams. Journal of Food Engineering, 41, 13-21.

Hassan, F.A.; Ismail, A.; Hamid, A.A.; Azlan, A. and Al-sheraji, S.H. (2011). Characterisation of fibre-rich powder and antioxidant capacity of Mangifera pajang K. fruit peels. Food Chemistry, 126, 283-288.

Herbafood. (2002). Herbacel AQ Plus. Apple and citrus fibre. Available from www.herbafood.de/eaqplus.pdf. Date November 2002.

Jaime, L.; Molla, E.; Fernandez, A.; Martin-Cabrejas, M.; Lopez Andreu, F. and Esteban, R. (2002). Structural carbohydrates differences and potential source of dietary fiber of onion (Allium cepa L.) tissues. Journal of Agricultural and Food Chemistry, 50, 122-128.

Jimenez, A.; Rodriguez, R.; Fernandez-Caro, I.; Guillen, R.; FernandezBolanos, J. and Heredia, A. (2000). Dietary fibre content of table olives processed under different European styles: Study of physicochemical characteristics. Journal of the Science of Food and Agriculture, 80, 1903-1908.

Kethireddipalli, P.; Hung, Y.C.; Phillips, R. O. and McWatters, K. H. (2002). Evaluating the role of cell material and soluble protein in the functionality of cowpea (Vigna unguiculata) pastes. Journal of Food Science, 67(1), 53-59.

Kuniak, L. and Marchessault, R. H. (1972). Study of crossing-linking reaction between epichorhydrin and starch. Starke, 4, 110-116.

Lamghari, R.; Sanchez, C.; El Boustani, E.; Maucourt, N. M.; Sauvaire, Y.; Mejean, L. and Villaume, C. (2000). Comparison of effects of prickly pear (Opuntia ficus indica sp.) fruits, arabic gum and citrus pectin on viscosity and in vitro digestibility of casein. Journal of the Science of Food and Agriculture, 80, 359-364.

Lario, Y.; Sendra, E.; García-Pérez, J.; Fuentes, C.; Sayas-Barberá, E., Fernández-López, J. and Pérez-Alvarez, J.A. (2004). Preparation of high dietary fibre powder from lemon juice by-products. Innovative Food Science and Emerging Technology 5, 113-117.

Larrauri, J. A. (1999). New approaches in the preparation of high dietary fibre powders from fruits by-products. Trends in Food Science and Technology, 10, 3-8.

Larrauri, J.A.; Borroto, B. and Crespo, A.R. (1997). Water recycling in processing orange peel to a high dietary fibre powder. Int. J. Food Sci. Tech., 32: 73-76.

Lee, S. C.; Prosky, L. and DeVries, J. W. (1992). Determination of total, soluble and insoluble fiber foods. Enzimatic-Gravimetric method, MesTris buffer. Collaborative study. Journal of the Association of Official Analytical Chemists, 75(3), 395-416.

Mullin, W.J.; Wolunetz, M.S.; Emery, J.P. and Brooks, L. (1993). The effect of varity, growing location and storage on the dietry fiber content of potatos. J. Food Composition and Analysis, 6: 316-323. 
Raghavendra, S.N.; Ramachandra-Swamy, S.R.; Rastogi, N.K., Raghavarao, K.S.M.S.; Kumar, S. and Tharanathan, R.N., (2006). Grinding characteristics and hydration properties of coconut residue: a source of dietary fibre. Journal of Food Engineering, 72, 281-286.

Ralet, M.C.; Della Valle, G. and Thibault, J.F. (1993). Raw and extruded fibre from pea hulls. I. Composition and physico-chemical properties. Carb Polymers, 20: 17-23.

Redgwell, R. J. and Fischer, M. (2005). Dietary fiber as a versatile food component: An industrial perspective. Molecular Nutrition and Food Research, 49, 521-535.

Robertson, J. A.; Monredon, F. D.; Dysseler, P.; Guillon, F.; Amado, R. and Thibault, T. F. (2000). Hydration properties of dietary fiber and resistant starch: a European collaborative study. Lebensmittel Wissenschaft und Technologie, 33, 72-79.

Rodriguez, R.; Jimenez, A.; Guillen, R.; Heredia, A. and Fernandez-Bolanos, J. (1999). Postharvest changes in white asparagus during refrigerated storage. Journal of Agricultural and Food Chemistry, 47, 3551-3557.

Rodriguez, R.; Jimenez, A.; Fernandez-Bolanos, J.; Guillen, R. and Heredia, A. (2006). Dietary fibre from vegetable products as source of functional ingredients. Trends in Food Science and Technology (17) 3-15.

Saeed, M. A. (2010). Food processing for catering in spas. Ph.D. Thesis, Food Science Dept., Fac. of Agric., Moshtohor, Benha Univ., Egypt.

Saleh, W.A.; Sharoba, A.M.; Bahlol, H.E. and El-Tanahy, H.H. (2012). Studies on Texture of some Foods. LAP LAMBERT Academic Publishing GmbH \& Co. KG, Saarbrucken, Deutschland.

Sanchez-Zapata, E.; Fernandez-Lopez, J.; Penaranda, M.; FuentesZaragoza, E.; Sendra, E.; Sayas, E. and Perez-Alvarez, J.A., (2011). Technological properties of date paste obtained from date by-products and its effect on the quality of a cooked meat product. Food Research International, 44:2401-2407.

Sanchez-Zapata, E.; Fuentes-Zaragoza, E.; Fernandez-Lopez, J.; Sendra, E.; Sayas, E.; Navarro, C. and Pérez-Alvarez, J.A. (2009). Preparation of dietary fibre powder from tiger nut (Cyperus esculentus) milk ("horchata") by-products and its physicochemical properties. Journal of Agricultural and Food Chemistry 57, 7719-7725.

Schieber, A.; Stintzing, F. C. and Carle, R. (2001). By-products of plant food processing as a source of functional compounds-recent developments. Trends in Food Science and Technology, 12, 401-413.

Sharoba, A.M.; El-Mansy, H.A. and Senge, B. (2012). Rheological and Mechanical Properties of Some Selected Foods. LAP LAMBERT Academic Publishing GmbH \& Co. KG, Saarbrucken, Deutschland.

Sosulski, F.W. and Wu, K.K. (1988). High-fiber breads containing field pea hulls, wheat, corn and wild oat brans. Cereal Chem., 65: 186-191.

Sowmya, M.S.; Jeyarani, T.; Jyotsna, R. and Indrani, D. (2009):Effect of replacement of fat with sesame oil and additives on rheological, microstructural, quality characteristics and fatty acid profile of cake. Food Hydrocolloids, 23: 1827-1836. 
Sudha, M.L.; Baskaran, V. and Leelavathi, K., (2007). Apple pomace as a source of dietary fibre and polyphenols and its effect on the rheological characteristics and cake making. Food Chemistry, 104, 686-692.

Toma, R.B.; Orr, P.H.; D.Appolonia, B.; Dintzis, F.R. and Tabekhia, M.M. (1979). Physical and chemical properties of potato peel as a source of dietary fiber in bread. Journal of Food Science, 44, 1407-1417.

Tudorica, C. M.; Kuri, V. and Breenan, C. S. (2002). Nutritional and physicochemical characteristics of dietary fiber enriched pasta. Journal of Agricultural and Food Chemistry, 50, 347-356.

Vazquez-Ovando, A.; Rosado-Rubio, G.; Chel-Guerrero, L. and BetancurAncona, D. (2009). Physicochemical properties of a fibrous fraction from chia (Salvia hispanica L.). Food Science and Technology, 42, 168-173.

Wilkins, M.R.; Suryawati, L.; Maness, N.O. and Chrz, D. (2007). Ethanol production by Saccharomyces cerevisiae and Kluyveromyces marxianus in the presence of orange-peel oil. World J. Microbiol. Biotechnol., 23 (8), 1161-1168.

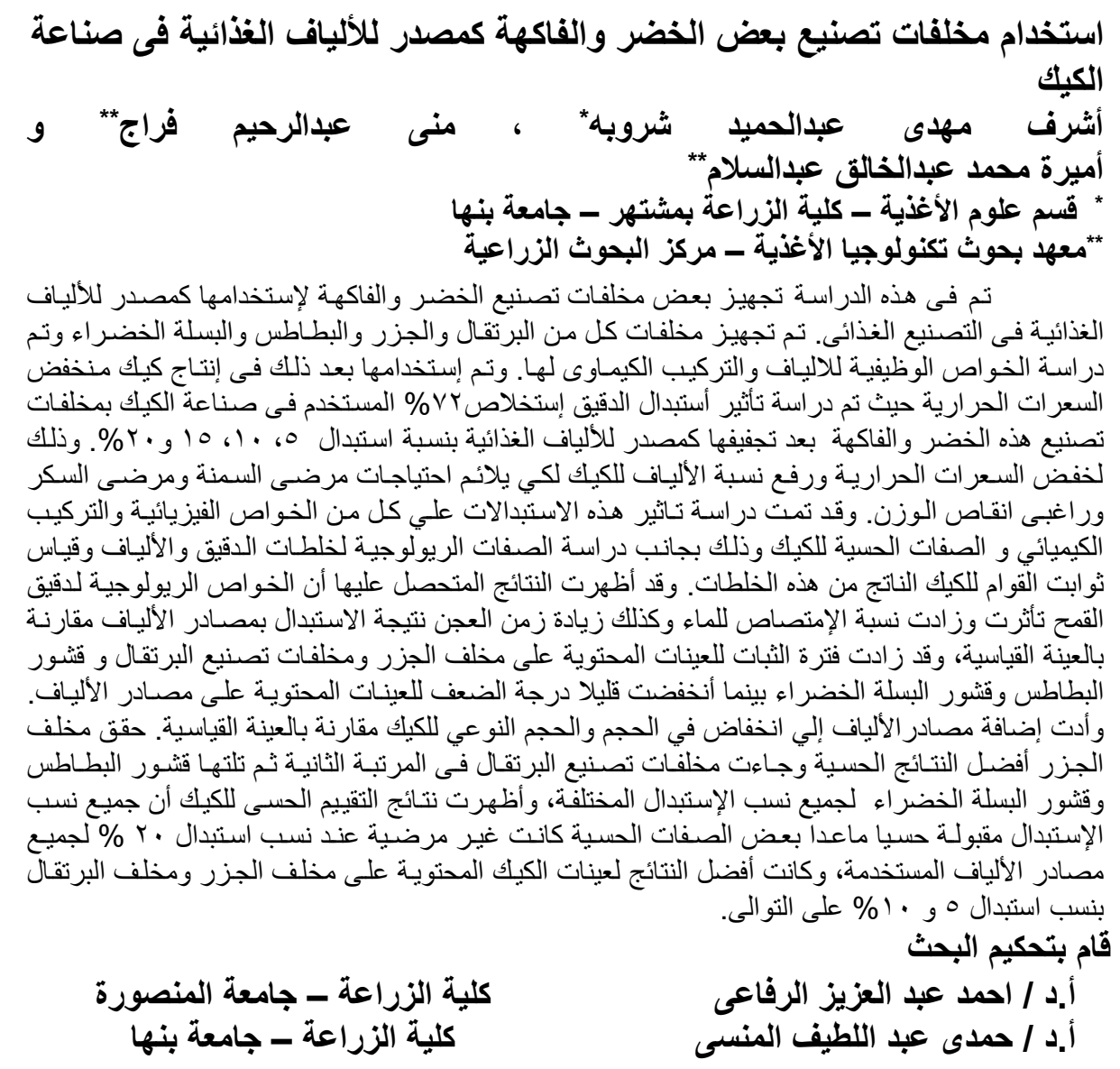


Sharoba, A.M. et al. 